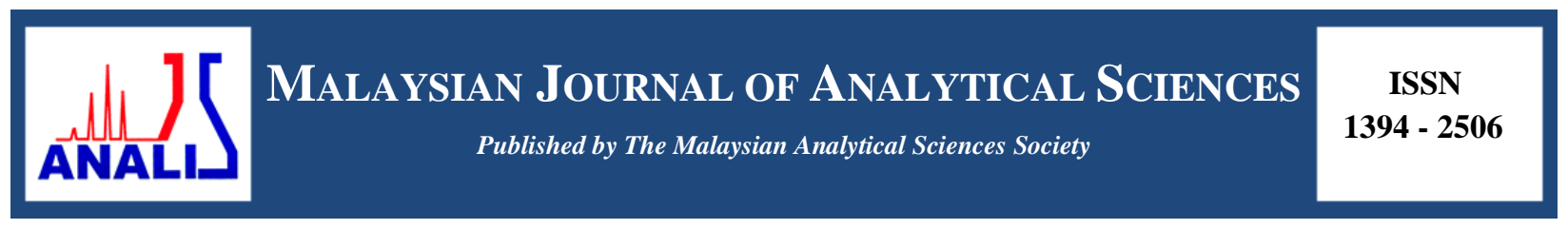

\title{
BITTERNESS AND PHYSICHOCHEMICAL PROPERTIES OF ANGELWING CLAM (Pholas orientalis) HYDROLYSATE
}

\author{
(Kepahitan dan Ciri - Ciri Fizikokimia Hidrolisat Mentarang (Pholas orientalis)) \\ Normah Ismail* and Nurul Fasihah Razak \\ Department of Food Technology, Faculty of Applied Sciences, \\ Universiti Teknologi MARA, 40450 Shah Alam, Selangor, Malaysia \\ *Corresponding author: norismel@salam.uitm.edu.my
}

Received: 24 February 2015; Accepted: 27 October 2015

\begin{abstract}
Protein hydrolysates from angelwing clam were obtained by enzymatic hydrolysis using bromelain. The bitterness of hydrolysates was evaluated based on the degree hydrolysis $(\mathrm{DH})$, sensory analysis, molecular weight distribution and functional group. By using $3 \%$ of enzyme substrate ratio bromelain resulted in high DH value at $12.57 \%$ when angelwing clam was hydrolysed for 2 hours. Sensory analysis showed that angelwing hydrolysate was bitter. Angelwing hydrolysate had molecular weight below $50 \mathrm{kDa}$. The lower molecular weight indicated that the protein has been degraded into smaller peptide chains which contribute to bitter taste. Moreover, the high peak of amine group in angelwing hydrolysate $\left(3385.6 \mathrm{~cm}^{-1}\right) \mathrm{suggested} \mathrm{that}$ bitterness exists. Angelwing hydrolysate had higher protein content, lower fat content and had good water holding capacity than the flesh. This result suggested that angelwing hydrolysate could be useful as food ingredient even though bitter taste developed after the hydrolysis. Thus, debittering should be considered in order to pave the way for full utilization of angelwing clam hydrolysate as a food ingredient.
\end{abstract}

Keywords: angelwing clam, sensory, hydrolysate, bromelain, bitterness, physicochemical properties

\begin{abstract}
Abstrak
Hidrolisat protein daripada kerang mentarang diperolehi daripada hidrolisis proses menggunakan enzim bromelain. Kepahitan hidrolisat dinilai berdasarkan tahap hidrolisis (DH), analisis deria, pengedaran berat molekul dan kumpulan berfungsi. Dengan menggunakan $3 \%$ daripada nisbah substrat enzim bromelain menyebabkan nilai DH tinggi pada $12.57 \%$ apabila kerang mentarang telah dihidrolisiskan selama 2 jam. Analisis deria menunjukkan kerang mentarang hidrolisat adalah pahit. Hidrolisat kerang mentarang mempunyai berat molekul di bawah $50 \mathrm{kDa}$. Berat molekul yang rendah menunjukkan bahawa protein yang telah dipecahkan kepada rantaian peptida yang lebih kecil menyumbang kepada rasa pahit. Selain itu, kumpulan amina yang mempunyai puncak yang tinggi dalam mentarang hidrolisat $\left(3385.6 \mathrm{~cm}^{-1}\right)$ menunjukkan bahawa kepahitan wujud. Hidrolisat kerang mentarang mempunyai kandungan protein yang lebih tinggi, kandungan lemak yang lebih rendah dan mempunyai keupayaan pegangan air yang lebih baik daripada daging. Hasil keputusan ini menunjukkan bahawa kerang mentarang hidrolisat boleh dimanfaatkan sebagai bahan makanan walaupun rasa pahit hadir selepas hidrolisis. Oleh itu, penyah-pahitan perlu dipertimbangkan untuk membuka jalan kepada penggunaan penuh kerang mentarang hidrolisat sebagai bahan makanan.
\end{abstract}

Kata kunci: mentarang, Pholas orientalis, hidrolisat, bromelain, kepahitan, ciri-ciri fizikokimia

\section{Introduction}

Angelwing clam (Pholas orientalis) is a marine bivalve found worldwide in countries such as France, Canada, Mexico, Japan, Australia, India, Papua New Guinea, Malaysia and Philippine [1]. In Malaysia, angelwing clam is 
abundantly found in Perlis, Kuala Kedah, Kuala Limau, Yan, Penaga, Telok Ayer Tawar and Kuala Selangor [2]. Protein hydrolysate is well-known protein rich by product that can be utilized as functional ingredients in food systems [3]. According to Jin et al. [4] marine bivalves protein hydrolysate has good functionalities such as high in solubility, water holding capacity, oil holding capacity and surface hydrophobicity. Besides, these marine bivalves protein hydrolysate has high nutritive value such as all essential amino acids that make it suitable to be multifunctional food ingredients. Zhou et al. [5] studies showed that bivalve mollusks such as scallop and abalone protein hydrolysate possessed a significant antioxidant ability that can replace the synthetic antioxidant.

The degree of bitterness that developed during hydrolysis are associated with the level of hydrophobic amino acids and the release of bitter taste peptides [6,7]. The size of peptide and lower molecular weight peptides are considered crucial to the sensation of bitterness [8].Therefore, the aim of this study was to investigate the development of bitter flavour in angelwing hydrolysate produced by bromelain.

\section{Raw materials}

\section{Materials and Methods}

Angelwing clam was purchased from Pantai Remis, Selangor, Malaysia. The clam was placed in ice and transported to the laboratory. Upon arrival the flesh was separated manually, washed and then stored at $-20{ }^{\circ} \mathrm{C}$. Bromelain $(1.5$ $\mathrm{AU} / \mathrm{g}$ ) was obtained from Novozymes.

\section{Preparation of angelwing clam protein hydrolysates}

Angelwing hydrolysate was prepared according to the methods by Normah and Fazlika [9] with some modification. An amount of $500 \mathrm{~g}$ angelwing clam flesh was mixed with $531.33 \mathrm{~mL}$ of distilled water and then minced. The mixture was transferred into $1 \mathrm{~L}$ beaker which was then placed in a water bath. The water bath was set at $45^{\circ} \mathrm{C}$ and the $\mathrm{pH}$ of the mixture was adjusted to 6 . Once the temperature and $\mathrm{pH}$ were constant, bromelain was added at $3 \%$ enzyme substrate ratio and the hydrolysis was performed for two hours. The mixture was continuously stirred at 200 rpm. The $\mathrm{pH}$ was kept constant throughout the hydrolysis by the addition of $1 \mathrm{~N} \mathrm{NaOH}$. At the end of the two hour hydrolysis, the reaction was terminated by heating at $90{ }^{\circ} \mathrm{C}$ for 15 minutes in a water bath. The mixture was then centrifuged (Hettich ZENTRIFUGEN, UNIVERSAL 320R) at $10000 \mathrm{rpm}$ at $4^{\circ} \mathrm{C}$ for 20 minutes. The supernatant was collected and freeze dried using SANYO-Biomedical freeze dryer.

\section{Degree of hydrolysis}

The percentage of solubilized protein in $10 \mathrm{~g}$ trichloroacetic acid (TCA), in relation to the total protein content of the sample was measured by the method of Silvestre et al. [10] with modification. After hydrolysis, $20 \mathrm{~mL}$ of protein hydrolysate was added to $20 \mathrm{~mL}$ of $20 \%$ (w/v) TCA to produced $10 \%$ TCA soluble material. The mixtures were left to stand for 30 minutes to allow precipitation followed by centrifugation at $7800 \mathrm{~g}$ for 15 minutes (Hettich ZENTRIFUGEN, UNIVERSAL 320R). Soluble protein content in $10 \%$ TCA and total protein content was detected by Lowry method. The DH is calculated as formula equation 1 :

$$
\mathrm{DH}=\frac{\text { soluble protein content in } 10 \mathrm{~g} \mathrm{TCA}(\mathrm{mg})}{\text { Total protein content }(\mathrm{mg})} \times 100
$$

\section{Evaluation of bitter taste}

The intensity of the bitter taste was conducted according to methods Nilsang et al. [7]. Samples were evaluated by 10 trained panelists who have been trained for three weeks using caffeine solution. Different concentrations of caffeine solutions at 0 to $1500 \mathrm{ppm}$ were prepared and presented to panelists. Panelists were instructed to rate the bitterness by marking a point on a $15 \mathrm{~cm}$ line scale. After each tasting, they were asked to rinse their mouth with $10 \% \mathrm{v} / \mathrm{w}$ citrus water and twice with warm water.

\section{Determination of molecular weight distribution by Sodium Dodecyl Sulfate Polyacrylamide Gel Electrophoresis (SDS-PAGE)}

An approximately $1 \mathrm{~g}$ of samples was mixed with $10 \mathrm{~mL}$ deionized water and then filtered using membrane filter with pore size $0.45 \mu \mathrm{m}$. An amount $6.5 \mu \mathrm{L}$ of the solution was mixed with $2.5 \mu \mathrm{L}$ NuPAGE®LDS sample Buffer $(4 \mathrm{X})$ and $1 \mu \mathrm{L}$ NuPAGE ${ }^{\circ}$ Reducing Agent $(10 \mathrm{X})$. The mixture was heated at $70^{\circ} \mathrm{C}$ for 10 minutes. $15 \mu \mathrm{L}$ sample was loaded into each well of the SDS-PAGE system comprising of $12 \%$ resolving gel and $5 \%$ stacking gel. 
Benchmark ${ }^{\mathrm{TM}}$ protein ladder with the range of 220 to $4.6 \mathrm{kDa}$ was used as a marker. Electrophoresis was performed using the XCell Surelock electrophoresis cell (Bio-Rad laboratories, Hercules, CA, USA). Electrophoresis was run for 50 minutes at 100-125 mA/gel. After the running process, the gels were washed with $100 \mathrm{~mL}$ of ultrapure water. Then, the gel was stained using Coomassie Brilliant Blue dye and heated in a microwave oven at $180{ }^{\circ} \mathrm{C}$ for one minute. The gel was shaken again in the orbital shaker for about 2 minutes. The process was repeated twice. The gels were destained using ultrapure water and shaken with orbital shaker for another 30 minutes.

\section{Functional group analysis}

The functional group analysis in samples was performed using Thermo Nicolet, Avatar 370a Fourier Transform Infer-Red Spectrophotometer (FTIR). This analysis was determined according to Normah et al. [6] with slight modification. The angelwing sample was ground using agate mortar until the particle size became so small (approximately 2.5 micron) that the surface of the solid appears shiny. An amount $0.08 \mathrm{~g}$ of powdered potassium bromide $(\mathrm{KBr})$ was added and the mixture was ground for about 30 seconds. The mixture was scraped into the middle and ground for another 15 seconds. The sample and $\mathrm{KBr}$ should be finely ground to avoid the mixture from scattering the infrared radiation excessively. The mixture was then placed in an evacuable mold and subjected to a pressure of 10 to 20MPa. Perkin Elmer Spectrum Software was used to control the spectrometer and data were collected over a wavenumber range of $4000-400 \mathrm{~cm}^{-1}$ with resolution of $4 \mathrm{~cm}^{-1}$ and collection spectra of 16 .

\section{Determination of fat content}

The extraction and determination of the fat content from the minced muscle or the hydrolysate sample were performed using the Soxhlet extraction method [11].

\section{Protein concentration}

Protein concentration was determined using the Lowry method based on the modified procedure of Hartree [12].

\section{Water holding capacity}

Water holding capacity (WHC) was determined using the centrifugation method according to Diniz and Martin [13].The samples $(0.5 \mathrm{~g})$ of hydrolysate was dissolved in $20 \mathrm{~mL}$ water in centrifuge tubes and dispersed with a vortex mixer for 30s. The dispersion was allowed to stand at room temperature for 6 hours, and subsequently centrifuged at $2800 \mathrm{~g}$ for $30 \mathrm{~min}$. The supernatant was filtered through Whatman filter paper No. 1 and the volume recovered was accurately measured. The difference between the initial volume of distilled water added to the protein sample and the volume of the supernatant were determined. The results were reported as $\mathrm{mL}$ of water absorbed per gram of protein sample (Equation 2).

$$
\text { WHC }\left(\frac{\mathrm{ml}}{\mathrm{g}}\right)=\frac{\text { Initial Volume of Distilled Water-Volume of supernatant }(\mathrm{ml})}{\text { Weight of Hydrolysate }(\mathrm{g})}
$$

\section{Degree of hydrolysis (DH)}

\section{Results and Discussion}

Hydrolysis at $\mathrm{pH} \mathrm{6,} \mathrm{E/S} \mathrm{3 \%} \mathrm{and} \mathrm{at} \mathrm{the} \mathrm{duration} \mathrm{of} 2$ hours produced $12.57 \%$ degree of hydrolysis by using bromelain. DH has been shown to be affected by the percent and type of enzyme used during the hydrolysis. Increasing the enzyme substrate ratio increased the DH as reported by Haslaniza et al. [14]. By increasing the enzyme concentration, the released peptides were further hydrolysed into amino acid and smaller peptide. According to Bhaskar et al. [15] degree of hydrolysis was higher at elevated temperatures as the degree of hydrolysis increased at increasing hydrolysis time and temperature. Besides, enzyme at given $\mathrm{pH}$ also affect the $\mathrm{DH}$ percentage as the optimum $\mathrm{pH}$ for higher rate of hydrolysis by using bromelain was at $\mathrm{pH} 6$ to 7 [16].

\section{Evaluation of bitter taste}

Quantitative descriptive analysis (QDA) was carried out by ten trained panelists and the result is presented in Figure1a. The scores of bitterness using a $15-\mathrm{cm}$ QDA line scale was 0.47 for the flesh, 9.49 for angelwing hydrolysate and 8.37 for caffeine reference solution. Angelwing hydrolysate was significantly $(\mathrm{p}<0.05)$ bitter compared to the reference solution. The angelwing hydrolysate taste mildly bitter when produced using bromelain. 
The bitter taste perceived in angelwing hydrolysate was due to the high amount of enzyme (E/S \%) used that contribute to the increased of DH [7]. This result was also supported by Seo et al. [17] where the small amount of $\mathrm{S} / \mathrm{E} \%$ at $0.5 \%$ bromelain used could gave a bitter taste to soy protein hydrolysate. According to Imelda [18] samples showed hydrolysis with different proteases had varying level of bitterness, where alcalase and protamex showed high level of bitterness within 1500 to 2000 ppm caffeine.

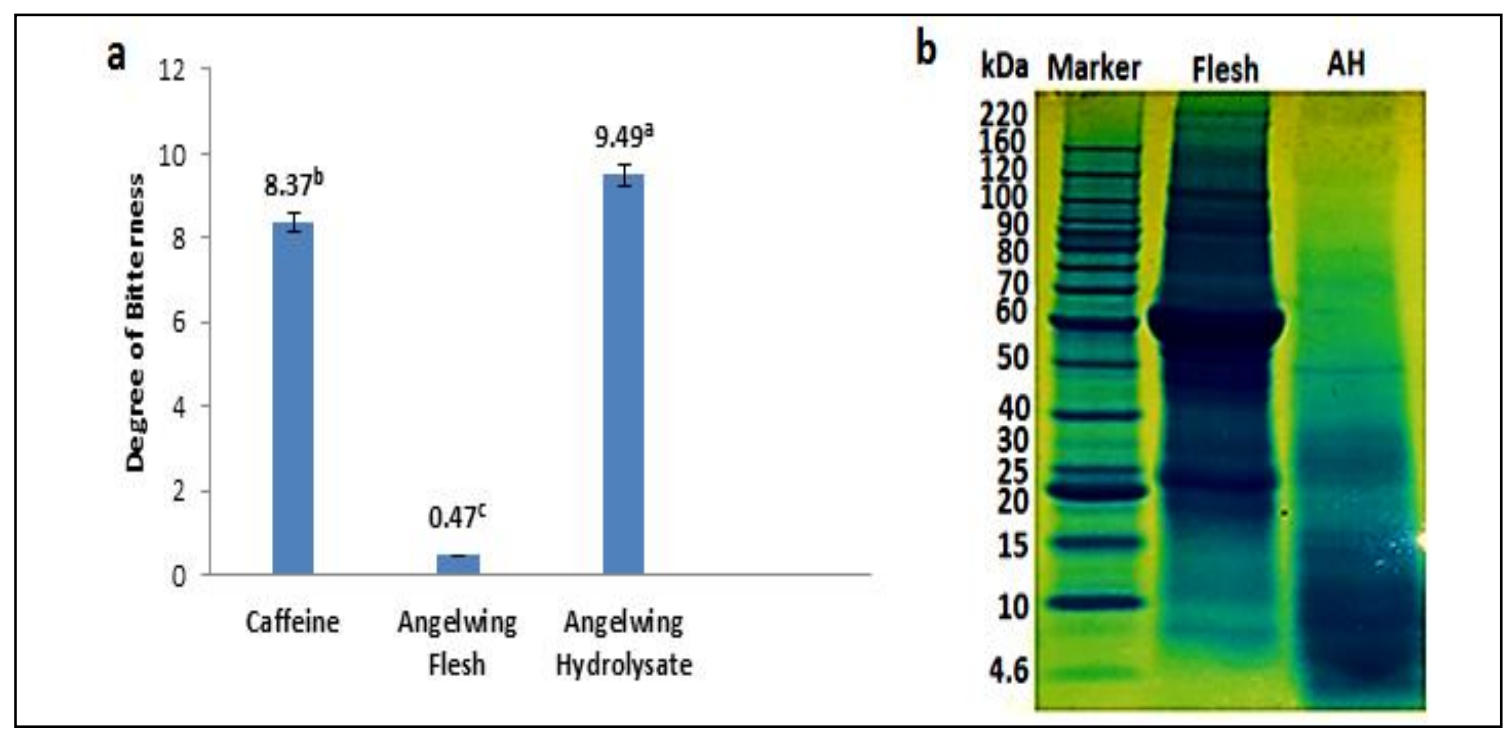

Figure 1. a) Degree of bitterness in caffeine solution, angelwing clam flesh and hydrolysate obtained by Quantitative Descriptive Analysis (QDA) where a, b, c (superscript) are significantly different $(\mathrm{p}<0.05)$ and b) Electrophoresis patterns of angelwing clam flesh and hydrolysates produced at $\mathrm{pH} 6,45^{\circ} \mathrm{C}$ for 2 hours by using bromelain.

\section{Molecular weight distribution of angelwing flesh and hydrolysate}

The electrophoresis patterns of angelwing flesh and hydrolysate are shown in Figure 1b. The flesh consists of many clear bands ranging from 9 to $220 \mathrm{kDa}$ compared to angelwing hydrolysate where clear bands were found very distinctly below $50 \mathrm{kDa}$. The absence of high molecular weight bands above $50 \mathrm{kDa}$ and the fade bands were at 90 , 80 and $60 \mathrm{kDa}$ showed that bromelain is capable of degrading most of the larger protein. According to Jefferey et al. [19] the smaller the peptide, the bitter is the hydrolysate. As shown in Figure 2, angelwing hydrolysate had thick bands at $4.6 \mathrm{kDa}$ and below compared to the flesh. This suggested that the bitterness was perceived after the hydrolysis. This result was in line with sensory analysis. According to Kristinsson and Rasco [20], molecular weight with protein below $10 \mathrm{kDa}$ contributed to the bitterness of hydrolysate. While Jeffery et al. [19] stated that bitterness develops when small to medium-sized of hydrophobic peptides $<18 \mathrm{kDa}$ were produced after hydrolysis process. This was also supported in previous study by Normal et al. [6], where green muscle hydrolysate produced using alcalase had molecular weight of $<3 \mathrm{kDa}$ were bitter. In this study, angelwing hydrolysate had bands below $15 \mathrm{kDa}$ that indicated the hydrolysate has smaller peptide compared to the flesh that contribute to bitterness.

\section{Functional group analysis}

The peak ranges between $3500-3200 \mathrm{~cm}^{-1}$ in Figures 2 represent the N-H of amine group. The functional group of angelwing hydrolysate showed high peak at $3385.6 \mathrm{~cm}^{-1}$ while the flesh showed a peak at $3305.65 \mathrm{~cm}^{-1}$. According to Agrawal and Chiddarwar [21] the functional groups that are usually present in the bitter drugs were amine group. Therefore, this result is in accordance with the sensory analysis which showed that angelwing hydrolysate was bitter due to the presence of the high peak of N-H groups. Besides, Figure 2 showed angelwing hydrolysate has peak bands at $1640 \mathrm{~cm}^{-1}$ while the flesh has a peak bands at $1654 \mathrm{~cm}^{-1}$ which attributed to the carbonyl $(\mathrm{C}=0)$ stretch 
vibration centered approximately between $1650 \mathrm{~cm}^{-1}-1540 \mathrm{~cm}^{-1}[22]$. These bands indicated the presence of functional compounds strong amide I and II in protein amide group $\left(-\mathrm{CONH}_{2}\right)$ which this amides of carboxylic acid $\left(\mathrm{RCONH}_{2}\right)$ were bitter [23].

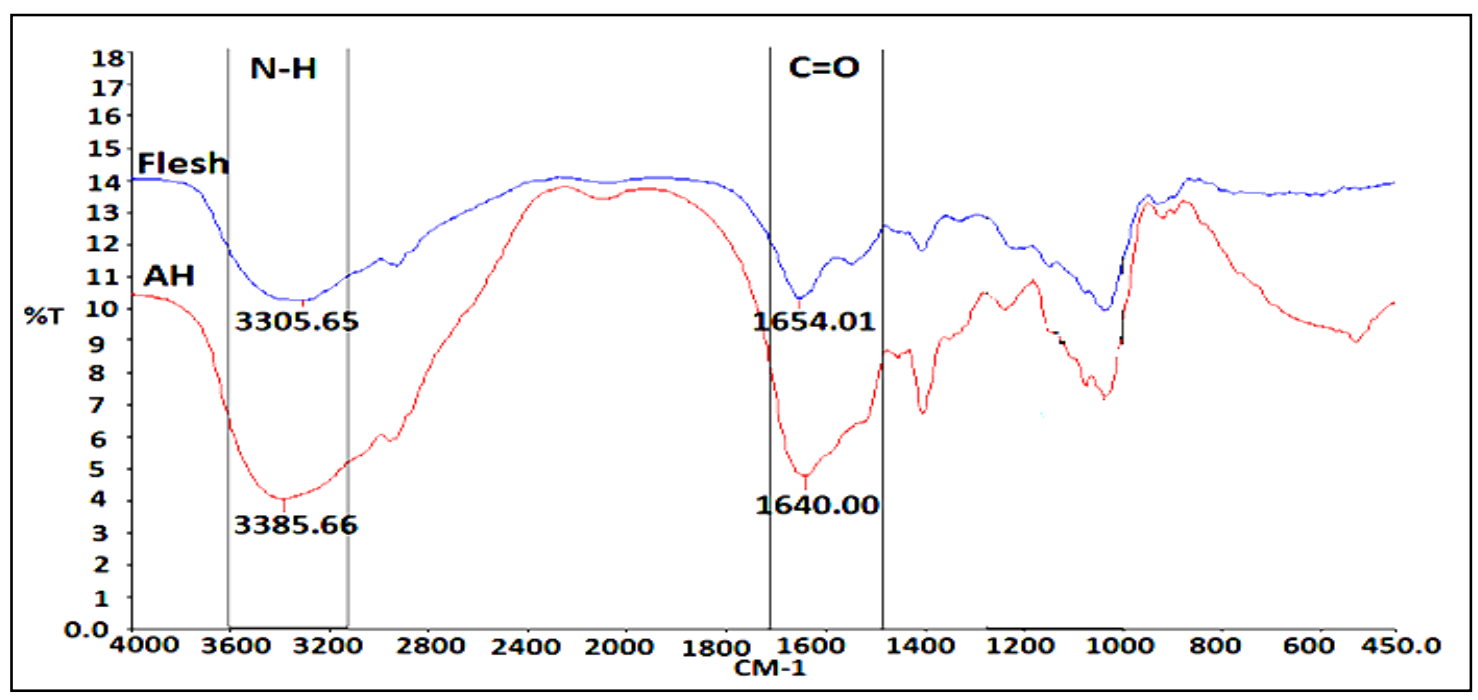

Figure 2. FTIR spectrums of angelwing clam flesh and hydrolysate (AH) produced at $\mathrm{pH} 6,45^{\circ} \mathrm{C}$ for 2 hours by using bromelain

\section{Protein, fat and water holding capacity}

Hydrolysis of angelwing clam increased the protein concentration in hydrolysate. Table 1, showed the hydrolysate contain $74.41 \%$ protein, which increased the protein content to $48.28 \%$ more than the flesh. These results were in line with DH where angelwing hydrolysate had high DH (12.10\%).Previous study stated that the higher DH gave higher protein content [24]. This is because protein that solubilized during hydrolysis contained in the layer of supernatant compared to its precipitate.

Table 1. The properties of angelwing clam flesh and hydrolysate produced at $\mathrm{pH} 6,45^{\circ} \mathrm{C}$ for 2 hours by using bromelain

\begin{tabular}{lcc}
\hline The properties of sample $^{\text {a }}$ & Flesh & Angelwing hydrolysate \\
\hline Protein content $(\%)$ & $25.91 \pm 0.19$ & $74.41 \pm 0.35$ \\
Fat content $(\%)$ & $6.43 \pm 0.09$ & $3.43 \pm 0.11$ \\
Water holding capacity (ml/g) & - & $4.60 \pm 0.25$ \\
\hline
\end{tabular}

${ }^{\mathrm{a}}$ Mean \pm SD from triplicate determination.

Fat content in the angelwing flesh $(6.43 \%)$ was higher compared to the hydrolysate $(3.43 \%)$. As the hydrolysis proceeds, the muscle cell membranes tended to roundup and form insoluble vesicles leading to the removal of membrane structured lipid [25]. The insoluble fraction (vesicles) was separated from the soluble hydrolysate in the form of pellet by centrifugation and removed prior to spray-drying [26]. Thus higher DH lead to higher fat removal.

The water-protein interaction is important factor for functional properties of proteins in food systems [27]. In this studies water holding capacity on powdered angelwing hydrolysate was $4.60 \mathrm{ml} / \mathrm{g}$ (Table 1). According to Amiza et 
al. [25] water holding capacity increased with an increased in degree of hydrolysis. Besides, at higher hydrolysis, polar groups such as $\mathrm{COOH}$ and $\mathrm{NH}_{2}$ increased thus gave significant effects on water absorption and tend to exert better water-holding capacity [22]. In this study the functional group analysis showed that NH group peak was higher in angelwing hydrolysate compared to the flesh thus support the finding by Kristinsson and Rasco [28]. Water holding capacity of partly unfolded and hydrolysed proteins is greater than that of the native proteins due to an increase in surface area to mass ratio with an exposure of some previously buried hydrophobic groups [29, 26]. Low-molecular weight peptides from high extent of enzymatic hydrolysis also appeared to be more effective in water-holding capacity than larger size peptides as smaller fragments of peptides are possibly more hydrophilic [30].

\section{Conclusion}

Angelwing hydrolysate has a potential to be good source of food ingredient. However the uses of bromelain in the preparation of angelwing hydrolysate resulted in bitter taste. Thus, further studies may need to be carried out using simple technique of debittering which can enhance the application of angelwing hydrolysate in the food industry.

\section{Acknowledgement}

The authors would like to thank for all the laboratory staff of Food Technology Department and facilities provided from Faculty of Applied Science, Universiti Teknologi Mara (UiTM), Shah Alam Campus.

\section{References}

1. Berthou, P., Poutiers, J. M., Goulletquer, P. and Dao, J.C. (2009). Shelled molluscs, in fisheries and agricultural from encyclopedia of life support systems (EOLSS), Developed under the Auspices of the UNESCO, Eolss Publishers, Oxford, UK, 1-19.

2. Bee Wah, N. (2009). Biological aspect and development of larvae and juvenile of the angelwing clam Pholas orientalis (Gmeline, 1971). Georgetown, Penang: Universiti Sains Malaysia, MSc Thesis, 1-24.

3. Herpandi, N., Huda, A., Rosma, A. and Wan Nadiah, W. A. (2012). Degree of hydrolysis and free tryptophan content of skipjack tuna (Katsuwonus pelamis) protein hydrolysates produced with different type of industrial proteases. International Food Research Journal, 19(3): 863 - 867.

4. Jin, W-G., Wu, H-T., Zhu, B-W. and Ran, X-Q. (2012). Functional properties of gelation-like protein hydrolysates from scallop (Patinopecten yessoensis) male gonad. European Food Research and Technology, 234(5): 863 - 872 .

5. Zhou, D-Y., Zhua, B-W., Qiao, L., Wua, H-T., Lia, D-M., Yanga, J-F. and Murata, Y. (2012). In vitro antioxidant activity of enzymatic hydrolysates prepared from abalone (Haliotis discus hannai Ino) viscera. Food and Bioproducts Processing, 90: 148 - 154.

6. Normah, I., Siti Hafsah, M. S. and Nurul Izzaira, A. (2013). Bitterness of green mussel (Perna viridis) hydrolysate as influenced by the degree of hydrolysis. Food Research International Journal, 20(5): 2261 2268.

7. Nilsang, S., Lertsiri, S., Suphantharika, M. and Assavanig, A. (2005). Optimization of enzymatic hydrolysis of fish soluble concentrate by commercial proteases. Journal Food Engineering, 70(4): 571 - 578.

8. Ramos de Armas, R., Diaz, H. G., Molina, R., Gonzalez, M. P. and Uriarte, E. (2004). Stochastic based descriptors studying peptides biological properties: modelling the bitter tasting threshold of peptides. Biorganic and Medicinal Chemistry, 12: 4815 - 4822.

9. Normah, I. and Nurfazlika Nashrah M. P. (2013). Evaluation on the properties of mentarang (Pholas orientalis) protein hydrolysate. Journal of Tropical Agricultural Science, 36 (2): 199 - 210.

10. Silvestre, M. P. C., Morais, H. A., Silva, V. D. M. and Silva, M. R. (2013). Degree of hydrolysis and peptide profile of whey proteins using pancreatin. Journal of the Brazilian Society for Food and Nutrition, 38(3):278 290.

11. AOAC. (2005). Official methods of analysis of international (16th ed.). Washington, DC: Association of Official Analytical Chemist.

12. Hartree, E. F. (1972). Determination of proteins: A modification of the lowry method that give a linear photometric response. Analytical Biochemistry, 48: 422 - 427.

13. Diniz, F. M. and Martin, A. M. (1997). Effects of the extent of enzymatic hydrolysis on functional properties of shark protein hydrolysate. Lebensmittel Wissenschaft and Technologies, 30: 266 - 272. 
14. Haslaniza, H., Maskat, M. Y. and Wan Aida, W. M. (2010). The effects of enzyme concentration, temperature and incubation time on nitrogen content and degree of hydrolysis of protein precipitate from cockle (Anadara granosa) meat wash water. International Food Research Journal 17: 147 - 152.

15. Bhaskar, N., Benila, T., Radha, C. and Lalitha, R. G. (2008). Protein hydrolysate from visceral waste proteins of catla (Catla catla): Optimization of hydrolysis conditions for a commercial neutral protease. Bioresource Technology, 99 (10): $4105-4111$.

16. Himonides, A. T., Taylor, A. K. D. and Morris, A. J. (2011). A study of Enzymatic Hydrolysis of Fish Frames Using Model System. Food and Nutrition Sciences, 2: 575 - 585.

17. Seo, W. W. H., Lee, H. G. and Baek, H. H. (2008). Evaluation of bitterness in enzymatic hydrolysates of soy protein isolate by taste dilution analysis. Journal of Food Science, 73: $41-46$.

18. Imelda, W.Y.C. (2007). Bitterness in enzymatically-produced hydrolysates of commercial shrimp (Pandalopsis dispar) processing waste. Kelowna, Canada: University of British Columbia, MSc thesis, 15 -185.

19. Jeffery, R. B., Mary, B., Charlotte, B., Marie, S., Kristen, H., Mark, E. J. and James, L. S. (2002). Contribution of Lactococcus lactis cell envelope proteinase specificity to peptide accumulation and bitterness in reduced-fat cheddar cheese. Applied and Environmental Microbiology, 68(4): 1778 - 1785.

20. Kristinsson, H. G. and Rasco, B. A. (2000). Fish protein hydrolysates: Production, biochemical and functional properties. Critical Reviews in Food Science and Nutrition, 40: 43 - 81.

21. Agrawal, V. A. and Chiddarwar, A. P. (2010). Taste abatement techniques to improve palatability of oral pharmaceuticals: A Review. International Journal of Pharmaceutical Research Development, 2: 1 - 10.

22. Oliver, C. M., Kher, A., McNaughton, D. and Augustin, M. A. (2009). Use of FTIR and mass spectrometry for characterization of glycated caseins. Journal Dairy Research, 76: $105-110$.

23. Charalambous, G. and Inglett, G. (2012). Instrumental analysis of food, Recent progress Vol 1. Academic Press. Inc., Fifth Avenue, New York, 315 - 316.

24. Dalgleish, D. G. and Hunt J. A. (1995). Protein-protein interactions in Food Materials, in Gaonkar, A.G. editor. Ingredient interactions effect on food quality. Marcel Dekker, Inc, $199-205$.

25. Amiza, M. A., Ow, Y. W. and Faazaz A. L. (2013). Physicochemical properties of silver catfish (Pangasius sp.) frame hydrolysate. International Food Research Journal, 20(3):1255 - 1262.

26. Shahidi, F., Han, X. Q. and Synowiecki, J. (1995). Production and characteristics of protein hydrolysates from capelin. Food Chemistry, 53: 285 - 293.

27. Kelfala Foh, M. B., Amodou, I., Mabel Foh, B., Kamara, M. T. and Xia, W. (2010). Functionality and antioxidant properties of tilapia (Oreochromis niloticus) as influenced by the degree of hydrolysis. International Journal of Molecular Science, 11 (4): 1851 - 1869.

28. Kristinsson, H. G. and Rasco, B. A. (2000). Biochemical and functional properties of Atlantic salmon (Salmo salar) muscle proteins hydrolyzed with various alkaline proteases. Journal of Agricultural \& Food Chemistry, 48(3): $657-666$.

29. Damodaran,S., Parkin, K. L. and Fennema, O. R. (2007). Fennema's food chemistry in amino acids, peptides and proteins. ( ${ }^{\text {th }}$ edition). CRC Press Taylor and Francis Group, Boca Raton, $321-430$.

30. Cumby, N., Zhong, Y., Naczk, M. and Shahidi, F. (2007). Antioxidant activity and water-holding capacity of canola protein hydrolysates. Journal of Food Chemistry, 109: 144 - 148. 